\title{
Ingestion of iron in sow's faeces by piglets reared in farrowing crates with slotted floors
}

\author{
By P. T. GLEED AND B. F. SANSOM \\ Agricultural Research Council, Institute for Research on Animal Diseases, Compton, \\ Newbury, Berkshire RG16 ONN
}

(Received 23 June 1981 - Accepted 17 September 1981)

\begin{abstract}
1. Two sows were housed in farrowing crates with slotted floors and fed daily with approximately $200 \mu \mathrm{Ci}^{198} \mathrm{Au}$ from $3 \mathrm{~d}$ before farrowing until their piglets were $21 \mathrm{~d}$ old.

2. The sows' faeces became radioactive but their milk remained free of radioactivity. The piglets' mean ( \pm SE) whole-body radioactivity was equivalent to $8.5 \pm 0.9 \mathrm{~g}$ (range $3.8-15.5 \mathrm{~g}$ ) of faeces. This is probably a measure of their daily intake of faeces.

3. The possibility of using this natural coprophagia to prevent piglet anaemia has been demonstrated on two commercial piggeries by feeding the sows a diet containing $2000 \mathrm{mg} \mathrm{Fe} / \mathrm{kg}$.
\end{abstract}

In a previous paper (Sansom \& Gleed, 1981) it was shown that piglets born to sows housed in solid-floored farrowing pens ingested on average $20 \mathrm{~g}$ of faeces and bedding daily. Although there were wide variations in the amounts ingested by individual piglets (range $5-85 \mathrm{~g} / \mathrm{d}$ ) it was suggested that this natural coprophagia could provide a simple means of supplying sufficient iron to prevent them from becoming anaemic. By providing $2000 \mathrm{mg}$ $\mathrm{Fe} / \mathrm{kg}$ dry matter (DM) in the diet of the sow the Fe content of her faeces would be increased to approximately $2 \mathrm{mg} \mathrm{Fe} / \mathrm{g}$ fresh material and every piglet would ingest at least $10 \mathrm{mg} \mathrm{Fe} / \mathrm{d}$. The estimated requirement of a piglet from birth to weaning at 3-5 weeks is 7-10 mg Fe/d (Venn et al. 1947).

However, in most farrowing houses the sows are housed in pens or crates in which the floors are either partially or wholly formed of slats or are made from pressed-steel sheets perforated with slots. Both forms of floor are designed to improve the cleanliness of the farrowing pens by allowing faeces and urine to drop through to collecting tanks beneath. In this system the piglets would have less access to the sow's faeces and supplementing the sow's diet with Fe would be less effective in preventing piglet anaemia.

These experiments were designed (1) to measure the quantity of faeces ingested by piglets reared in a farrowing crate with a slotted steel floor and (2) to assess the efficacy for preventing piglet anaemia of supplementing the diet of lactating sows with $2000 \mathrm{mg} \mathrm{Fe} / \mathrm{kg} \mathrm{DM}$ as $\mathrm{FeSO}_{4} .7 \mathrm{H}_{2} 0$, the sows being kept in commercial piggeries using farrowing pens or crates with slatted floors.

\section{MATERIALS AND METHODS}

Expt 1

Two Large White $\times$ Landrace sows and their litters were used. At $3 \mathrm{~d}$ before they were expected to farrow the sows were moved into the farrowing crate (PIC, Camborough Farrowing System) and thereafter were dosed daily with approximately $200 \mu \mathrm{Ci}{ }^{198} \mathrm{Au}$ (Code GCS-IP; The Radiochemical Centre, Amersham, Bucks.) as described previously until the piglets were $21 \mathrm{~d}$ old. No bedding material was supplied except for some wood shavings in the solid-floored creep area. The piglets' whole-body radioactivity and the radioactivity of the sows' daily output of faeces were measured daily as before in a whole-body counter (Sansom et al. 1971). When the piglets were $21 \mathrm{~d}$ old they were slaughtered, washed 
Table 1. Mean whole-body radioactivity (counts/s) in the piglets of two sows given $200 \mu \mathrm{Ci}$ ${ }^{198}$ Au daily, mean radioactivity (counts/s) in fresh faeces and the calculated mean quantity of faeces present in the piglets $(\mathrm{g})$

(Mean values with their standard errors)

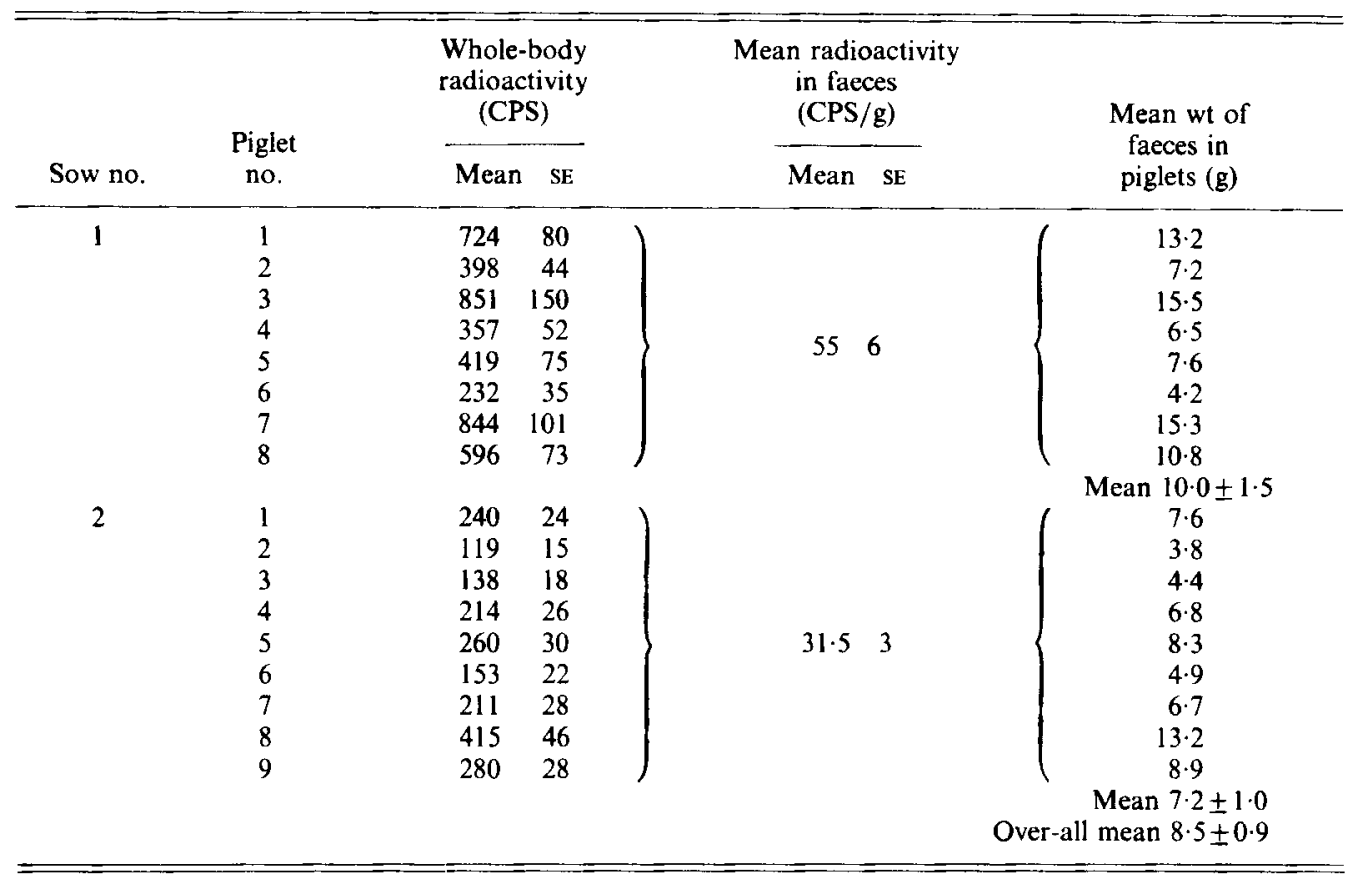

thoroughly and counted in the whole-body counter. The gastrointestinal tract was then removed and the empty carcase recounted.

\section{Expt 2}

Two commercial piggeries, A and B, were used; their systems of management were as follows.

Piggery $A$. The farrowing house consisted of several rooms each containing eight concrete pens divided by a central corridor into two groups of four pens. Each sow was housed in a tubular steel crate behind which the floor was slatted. From 2-3 d before farrowing each group of four sows was given either a home-produced diet containing approximately $400 \mathrm{mg} \mathrm{Fe} / \mathrm{kg}$ or the same diet supplemented with $10 \mathrm{~kg} \mathrm{FeSO}_{4} \cdot 7 \mathrm{H}_{2} \mathrm{O} /$ tonne - an additional $2000 \mathrm{mg} \mathrm{Fe} / \mathrm{kg}$. The piglets born to sows fed on the normal diet were injected intramuscularly with $200 \mathrm{mg} \mathrm{Fe}$ as Fe-dextran when 2-4 days of age, whereas the piglets born to sows given the Fe-enriched diet received no extra Fe. The piglets were weaned at between 16 and 21 $\mathrm{d}$ of age (mean $17 \mathrm{~d}$ ).

Piggery $B$. The farrowing houses each contained approximately forty metal farrowing crates with slotted floors similar to those used in Expt 1. It was not possible to feed different diets to the sows in one farrowing house and the two treatments were therefore compared between farrowing houses. From $2-3 \mathrm{~d}$ before farrowing sows in one house were given their usual commercial diet containing approximately $400 \mathrm{mg} \mathrm{Fe} / \mathrm{kg}$ while the sows in another house were given the same diet enriched with $2000 \mathrm{mg} \mathrm{Fe} / \mathrm{kg}$ as $\mathrm{FeSO}_{4} \cdot 7 \mathrm{H}_{2} \mathrm{O}$. The piglets born to the sows on the different diets were either injected or not injected with $200 \mathrm{mg} \mathrm{Fe}$ as at piggery $\mathrm{A}$. The piglets were weaned at 5 weeks of age. 
Table 2. The numbers of litters and piglets on each treatment at two commercial piggeries, $A$ and $B$, and the mean weights, RBC, MCV, PCV, Hb and WBC of the piglets at weaning

(Mean values with their standard errors)

\begin{tabular}{|c|c|c|c|c|c|c|c|}
\hline \multirow[b]{2}{*}{ Piggery } & & \multicolumn{3}{|c|}{$\begin{array}{c}\text { Normal diet }+ \\
200 \mathrm{mg} \mathrm{Fe} \text { dextran }\end{array}$} & \multicolumn{3}{|c|}{$\begin{array}{l}2000 \mathrm{mg} \mathrm{Fe} / \mathrm{kg} \text { diet, } \\
\text { no added } \mathrm{Fe} \text { dextran }\end{array}$} \\
\hline & & Mean & SEM & $n$ & Mean & SEM & $n$ \\
\hline \multirow[t]{9}{*}{ A } & Litters & - & - & 23 & - & - & 24 \\
\hline & Pigs & - & - & 208 & - & - & 191 \\
\hline & Pigs/litter & - & - & $9 \cdot 0$ & - & - & 8.0 \\
\hline & Weight $(\mathrm{g})$ & 4079 & 72 & 208 & 4078 & 76 & 191 \\
\hline & $\left.\operatorname{RBC} 10^{6} / \mathrm{mm}^{3}\right)$ & 548 & $5 \cdot 1$ & 193 & 557 & $4 \cdot 8$ & 179 \\
\hline & $\operatorname{MCV}\left(\mu \mathrm{m}^{3}\right)$ & $71 \cdot 4$ & 0.5 & 192 & $71 \cdot 3$ & 0.5 & 179 \\
\hline & $\operatorname{PCV}(\%)$ & 39.9 & 0.4 & 192 & 40.4 & 0.3 & 179 \\
\hline & $\mathrm{Hb}(\mathrm{g} / 100 \mathrm{ml})$ & $12 \cdot 2$ & 0.12 & 193 & 12.5 & 0.08 & 179 \\
\hline & $\mathrm{WBC}\left(10^{3} / \mathrm{MM}^{3}\right)$ & 11.6 & 0.3 & 193 & 11.7 & 0.3 & 179 \\
\hline \multirow[t]{9}{*}{ B } & Litters & - & - & 14 & - & - & 16 \\
\hline & Pigs & - & - & 127 & - & - & $\begin{array}{l}10 \\
163\end{array}$ \\
\hline & Pigs/litter & -- & - & 9.1 & - & - & 10.2 \\
\hline & Weight $(g)$ & 7829 & 156 & 127 & $\overline{7972}$ & 152 & $\begin{array}{l}10 \cdot 2 \\
163\end{array}$ \\
\hline & $\operatorname{RBC}\left(10^{8} / \mathrm{mm}^{3}\right)$ & 666 & 6.0 & 119 & 641 & $6 \cdot 0$ & 154 \\
\hline & $\operatorname{MCV}\left(\mu \mathrm{m}^{3}\right)$ & 63 & $0 \cdot 3$ & 119 & 57 & 0.4 & 154 \\
\hline & PCV $(\%)$ & 42.6 & 0.4 & 119 & 36.1 & 0.5 & 154 \\
\hline & $\mathrm{Hb}(\mathrm{g} / 100 \mathrm{ml})$ & $13 \cdot 2$ & $0 \cdot 1$ & 119 & 11.6 & $0 \cdot 1$ & 154 \\
\hline & WBC $\left(10^{3} / \mathrm{mm}^{3}\right)$ & $18 \cdot 0$ & $0 \cdot 4$ & 119 & 17.9 & 0.4 & 154 \\
\hline
\end{tabular}

At weaning the piglets in both piggeries were weighed and a blood sample was taken from the anterior vena cava, using EDTA as anticoagulent. The blood samples were analysed for erythrocytes (RBC), mean corpuscular volume (MCV), packed cell volume (PCV) and leucocytes (WBC) using a Coulter counter. Haemoglobin $(\mathrm{Hb})$ was measured by the cyanmethaemoglobin method.

\section{RESULTS \\ Expt 1}

As in the previous experiment (Sansom \& Gleed, 1981) the piglets' whole-body radioactivity increased quickly but tended to fluctuate about a mean rather than to increase steadily with time. Table 1 shows the mean whole-body radioactivity of each piglet and the mean radioactivity of the faeces of the two sows. The quotient of these quantities gives the mean quantity of faeces present in each piglet during the $21 \mathrm{~d}$ of the experiment.

At slaughter the mean ( \pm SE) percentage of the whole-body radioactivity present in the piglets' gastrointestinal tracts was $94.0 \pm 1.06 \%$.

\section{Expt 2}

Table 2 shows the numbers of litters and piglets on each treatment at each piggery, their weights (mean \pm SEM) at weaning and the mean ( \pm SEM) values of $\mathrm{RBC}, \mathrm{MCV}, \mathrm{PCV}, \mathrm{Hb}$ and WBC. 


\section{DISCUSSION}

Expt 1

The farrowing crates were cleaned daily and it was observed that there were always faeces on the floor as well as beneath. In this experiment no bedding was supplied to the sow, and the piglets therefore always had access to radioactive faeces which were undiluted with bedding. The average radioactivity in the piglets was therefore directly equivalent to the presence of $8.5 \mathrm{~g}$ of faeces with a range among individual piglets of $3.8-15.5 \mathrm{~g}$. As was pointed out in the previous paper (Sansom \& Gleed, 1981) these quantities can be converted into the quantities of faeces ingested daily only by making an assumption about the average time taken for the material to pass through the gastrointestinal tract. By assuming a passage time of $24 \mathrm{~h}$ the average weight of faeces present can be equated to the average weights ingested daily and the results of these experiments can be compared with those from the experiments in solid-floored farrowing pens (Sansom \& Gleed, 1981).

As expected the piglets of these two sows ingested less faeces (approximately $8.5 \mathrm{~g} / \mathrm{d}$ ) than those of sows housed in solid-floored pens (approximately $20 \mathrm{~g} / \mathrm{d}$ ). However, the range of quantities ingested $(3 \cdot 8-15 \cdot 5 \mathrm{~g} / \mathrm{d})$ would still make it possible to supplement the piglets adequately with $\mathrm{Fe}$ provided that the sow's diet contained sufficient $\mathrm{Fe}$.

\section{Expt 2}

At both piggeries the piglets born to sows given diets enriched with $2000 \mathrm{mg} \mathrm{Fe} / \mathrm{kg}$ were well protected from clinically significant anaemia, whether that be defined as a haemoglobin concentration less than $6 \mathrm{~g} / 100 \mathrm{ml}$ (Matrone et al. 1960) or less than $8 \mathrm{~g} / 100 \mathrm{ml}$ (Agricultural Research Council, 1967). Indeed, at piggery A the piglets of sows fed on the Fe-enriched diet had as high levels of $\mathrm{RBC}, \mathrm{PCV}$ and $\mathrm{Hb}$ as those which received direct intramuscular injections of $200 \mathrm{mg} \mathrm{Fe}$ as Fe-dextran. There were no differences in other haematological values or in the mean weight of the piglets at weaning. At piggery $B$, the RBC, PCV and $\mathrm{Hb}$ values of the piglets born to sows given the Fe-enriched diet were all significantly lower than in piglets injected with Fe-dextran. At this piggery the farrowing crates were cleaned thoroughly every day whereas at piggery $A$ the crates were cleaned less frequently. As a result the sows at piggery $B$ tended to be cleaner and faeces were less readily available to the piglets than at piggery $A$; this difference may account for the lower haematological values. However, there was no difference between the mean weights of the two groups of piglets at weaning.

The concentration of $\mathrm{Fe}$ in the faeces of sows given $2000 \mathrm{mg} \mathrm{Fe} / \mathrm{kg}$ diet is approximately $2 \mathrm{mg} \mathrm{Fe} / \mathrm{g}$ fresh faeces. In Expt 1 it was estimated that piglets reared in farrowing crates with slotted floors ingested between 3.8 and $15.5 \mathrm{~g}$ fresh faeces daily. This quantity should provide between 7 and $30 \mathrm{mg} \mathrm{Fe}$, ample to prevent anaemia if the $\mathrm{Fe}$ is readily available. The effectiveness of the Fe-enriched sow diet in preventing piglet anaemia at these two commercial piggeries suggests that the piglets were ingesting substantial quantities of faeces daily and that the Fe was available for absorption.

The sows at both piggeries accepted the Fe-enriched diet readily. At piggery $\mathrm{A}$, the diet was given as a powdered meal and there was no reduction in feed intake. At piggery $B$, the diet was given as a cubed pellet and a few gilts were reported to be reluctant to accept the change of diet on coming in to the farrowing house. However, there were no significant effects on performance (Table 2).

These experiments show that piglets ingest some of the sow's faeces even when accommodated in pens with slatted floors, and that by feeding the sows an Fe-enriched diet this natural coprophagia can be used to prevent them from becoming anaemic. 


\section{REFERENCES}

Agricultural Research Council (1967). Nutrient Requirements of Farm Livestock. No. 3, Pigs. London: H.M. Stationery Office.

Matrone, G., Thomason, E. J. Jr. \& Bunn, C. R. (1960). J. Nutr. 72, 459.

Sansom, B. F. \& Gleed, P. T. (1981). Br. J. Nutr. 46, 451.

Sansom, B. F., Taylor, P. J., Wheelock, D. \& Vagg, M. J. (1971). In Mineral Studies with Isotopes in Domestic Animals, p. 125. Vienna: International Atomic Energy Agency.

Venn, J. A. J., McCance, R. A. \& Widdowson, E. M. (1947). J. Comp. Path. 57, 314. 